\title{
Development of the Strength of the Fluidized Bed Combustion Fly Ash Based Geopolymer in Time
}

\section{Natalia Paszek and Marcin Górski}

Silesian University of Technology, Faculty of Civil Engineering, Department of Structural Engineering, Akademicka 5, Gliwice, Poland

\section{Abstract}

This paper presents a study into the mechanical behaviour of Fluidized Bed Combustion (FBC) fly ash based geopolymer. FBC fly ash is a by-product of a burning of a solid fuel (hard coal in case of this study) in a furnace at a low temperature. FBC fly ash is a type of a waste which is more difficult to recycle than pulverized fly ash. Using FBC fly ash in geopolymers offers one possible way to recycle it. The main goals of the investigation were to determine the influence of curing temperature and curing conditions on the strength of FBC fly ash based geopolymer; to determine the changes of strength over time and the changes of the temperature inside the geopolymer during the curing process. Tests have shown that the strength of the geopolymer generally increases in line with the increase of a curing temperature. The compressive strength stabilizes after 5 days of curing and yet continues to gain extra strength over the longer term. The flexural behaviour is not monotonic and therefore hard to predict. The temperature inside the geopolymer rises rapidly until reaching around $27.5^{\circ} \mathrm{C}$ and then decreases steadily.

Corresponding Author:

Natalia Paszek

natalia.paszek@polsı.pl

Received: 20 March 2020

Accepted: 30 April 2020

Published: 13 April 2020

Publishing services provided by Knowledge E

(c) Natalia Paszek and Marcin

Górski. This article is distributed under the terms of the

Commons Attribution License,

which permits unrestricted use and redistribution provided that the original author and source are credited.

Selection and Peer-review under the responsibility of the RICON19 - REMINE International Conference Conference Committee.

\section{G OPEN ACCESS}

Keywords: geopolymer, Fluidized Bed Combustion Fly ash, temperature, strength

\section{Introduction}

Fluidized bed combustion (FBC) is becoming increasingly popular, especially in the smaller factories. Thanks to the relatively low temperature of combustion (around 800$900^{\circ} \mathrm{C}$ ) and the low release of $\mathrm{SO}_{2}$ and $\mathrm{NO}_{x}$ contents in the flue gas, the $\mathrm{FBC}$ is perceived as more environmentally friendly than the other combustion processes. FBC also offers the possibility of burning different types of fuels in an economical way $[1,2]$. Non-spherical grains, the lack of the glassy phase, the relatively big content of an unburned carbon, the variability of chemical composition and the high content of free $\mathrm{SO}_{3}$ and $\mathrm{CaO}$ are factors differing $\mathrm{FBC}$ fly ash from ordinary fly ash and simultaneously, limiting the possibility of its exploitation in the traditional concrete technology [2-4]. Nevertheless, because of the need of the utilization of FBC fly ashes, scientists are still doing investigations and trying to use FBC fly ash in the concrete technology [5-8]. 
Glinicki et al. [6] identified the influence of FBC fly ash coming from hard coal and lignite combustion on the strength of the microstructure of the cement paste. Scientists report that the addition of FBC fly ash can improve the flexural strength by about 13$39 \%$ and the compressive strength by about $6-58 \%$ in dependence of the quantity and type of FBC fly ash addition. During the tests, cement was replaced by FBC fly ash in $20 \%$ and $30 \%$ by mass. Samples containing FBC fly ash coming from the lignite burning obtained slightly smaller compressive strengths than those with FBC fly ash coming from hard coal burning.

The other investigations include the possibility of the exploitation of FBC fly ash in the underwater concretes [3], in autoclaved aerated concrete [9] or together with slag in the autoclaved bricks [10].

The geopolymers give plenty of potential utilization options for FBC fly ash. The attributes and potential application for FBC coal fly ash in geopolymer was investigated and described precisely by Wu et al. [11]. During this study, two different types of FBC fly ash were examined and compared with conventional fly ash. The main differences were depicted: bigger content of $\mathrm{CaO}, \mathrm{SO}_{3}, \mathrm{Fe}_{2} \mathrm{O}_{3}$ and alkali metal; higher crystallinity; higher water demand and coarser particles in FBC fly ashes in comparison to conventional fly ash. The geopolymer binder was prepared by adding sodium hydroxide water solution to each fly ash sample. Tests have shown that the conventional fly ash based geopolymer obtains almost two times higher compressive strength than the FBC fly ash based one. The main possible reasons for this disproportion were: the finer particles, the lower crystallinity and the higher Al and Si content of conventional fly ash [11]. Studies done by Oyun-Erdene et al. confirm that mechanical activation of FBC fly ash improves significantly the strength of the FBC fly ash based geopolymer [12]. Grinding of FBC fly ash to improve its performance was also applied by Chindaprasirt et al. [1]. During this research it was also found that the strength as well as an acid and salt attack resistance of the FBC fly ash based geopolymer can be enhanced by the addition of pulverized coal combustion high calcium fly ash to the mixture. Duan et al. [13] report that FBC fly ash and the metakaolin based geopolymer has better high temperature and acid resistance than the ordinary Portland cement concrete.

The FBC fly ash based geopolymers characteristics depend on many factors, among the others on the chemical composition of fly ash, the composition of the mixture and on the curing conditions. The paper presents results of the investigation of the geopolymer based on FBC fly ash coming from Polish power plant located in Jaworzno. 


\section{Laboratory Tests}

The main goal of the laboratory tests was to establish the changes in the strength of FBC fly ash based geopolymer in time. The paper presents also the influence of the curing temperature and conditions on the mechanical behaviour of the geopolymer. The changes of the temperature inside the geopolymer sample are also included. The strength tests were done on the prismatic samples of dimensions $40 \times 40 \times 160 \mathrm{~mm}$ according to the standard EN 196-1 [14].

\subsection{Mixture composition}

All samples contained FBC fly ash and aquatic solutions of sodium silicate and sodium hydroxide. The chemical composition of FBC fly ash is given in Table 2. Sodium silicate had a $\mathrm{SiO}_{2} / \mathrm{Na}_{2} \mathrm{O}$ molar ratio between 2,4 and 2,6. According to the producent, the minimum content of oxides $\left(\mathrm{SiO}_{2}\right.$ and $\left.\mathrm{Na}_{2} \mathrm{O}\right)$ was $39 \%$. The sodium hydroxide solution was prepared for minimum 24 hours before the preparation of the mixture. The sodium hydroxide pellets were dissolved in demineralized water in such amount to obtain the solution of concentration $10 \mathrm{~mol} / \mathrm{l}$. The exact composition of the mixture used in all tests is presented in Table 1. The particle size distribution of the FBC fly ash is presented in Figure 1.

TABLE 1: Mixture composition.

\begin{tabular}{|l|c|c|c|}
\hline & FBC fly ash & Sodium silicate & Sodium hydroxide \\
\hline$\left[\mathrm{kg} / \mathrm{m}^{3}\right]$ & 997,4 & 700,5 & 233,1 \\
\hline$[\%]$ & 51,7 & 36,3 & 12,1 \\
\hline
\end{tabular}

\subsection{Preparation of the samples}

The preparation process was the same for all series of samples. Firstly, the activators (sodium silicate and sodium hydroxide) were mixed for five minutes. After that, the activators were mixed with FBC fly ash with the use of the mechanical mixer. The mixture was placed in the prismatic moulds. The influence of the curing condition on the strength of the samples was the subject of the first part of the research. In that part, four series of samples were prepared. Two first batches were cured all the time at the room temperature (about $20^{\circ} \mathrm{C}$ ). The first batch was demoulded after 24 hours. The second batch was demoulded in the day of strength tests. The third and fourth batches 
of samples were cured for the first 24 hours in the climatic chamber at humidity $40 \%$ and temperature $40^{\circ} \mathrm{C}$ and $60^{\circ} \mathrm{C}$ consecutively. Both batches were demoulded after 24 hours and stayed at the room temperature for the rest 6 days.

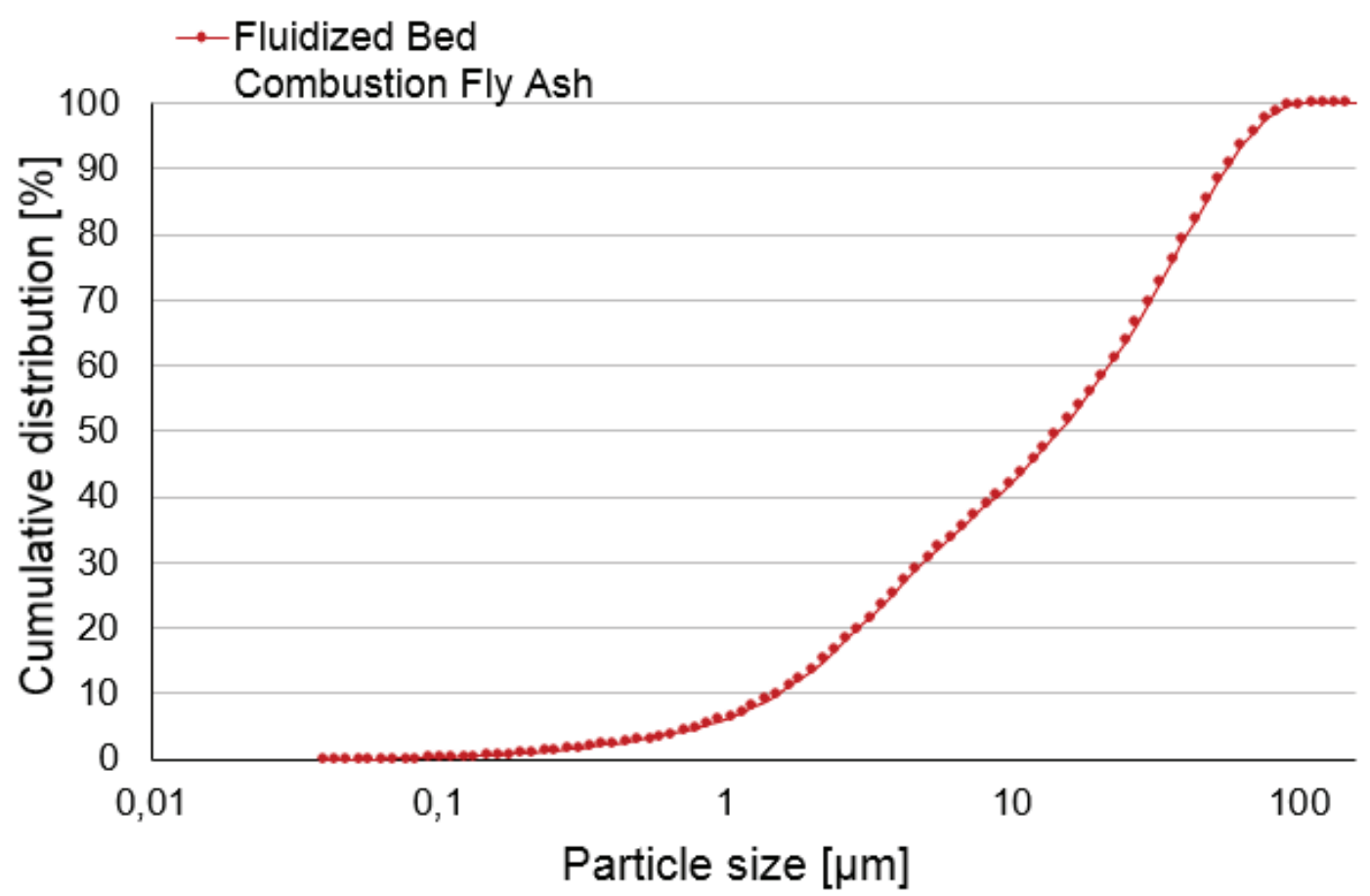

Figure 1: The particle size distribution of the FBC fly ash.

The influence of time on the mechanical behaviour of the FBC fly ash based geopolymer was determined on the samples cured for the first 24 hours at temperature $40^{\circ} \mathrm{C}$. For this purpose, the next four groups of samples were prepared. The groups were tested after 1, 5, 14 and 100 days.

The one of the goals of the research was to measure the temperature changes inside the FBC fly ash based geopolymer during the curing process at the room temperature. The DS thermometers were used for the measurement of the temperature. The thermometers were stabilized in the half of height of the mould, on two ends of each sample (see Figure 2). The temperature was registered in the two samples. The temperature was measured since for a while before the placing of the mixture into the moulds what allowed registering of the temperature during the whole process of the curing.

TABLE 2: The chemical composition of the FBC fly ash.

\begin{tabular}{|l|c|c|c|c|c|c|c|c|}
\hline & $\mathrm{SiO}_{2}$ & $\mathrm{Al}_{2} \mathbf{O}_{3}$ & $\mathrm{CaO}$ & $\mathbf{C}$ & $\mathrm{Fe}_{2} \mathbf{O}_{3}$ & $\mathbf{K}_{2} \mathbf{O}$ & $\mathbf{M g O}$ & $\mathbf{C l}$ \\
\hline$[\%]$ & 45,04 & 30,88 & 8,13 & 6,88 & 4,29 & 2,10 & 1,86 & 0,82 \\
\hline
\end{tabular}



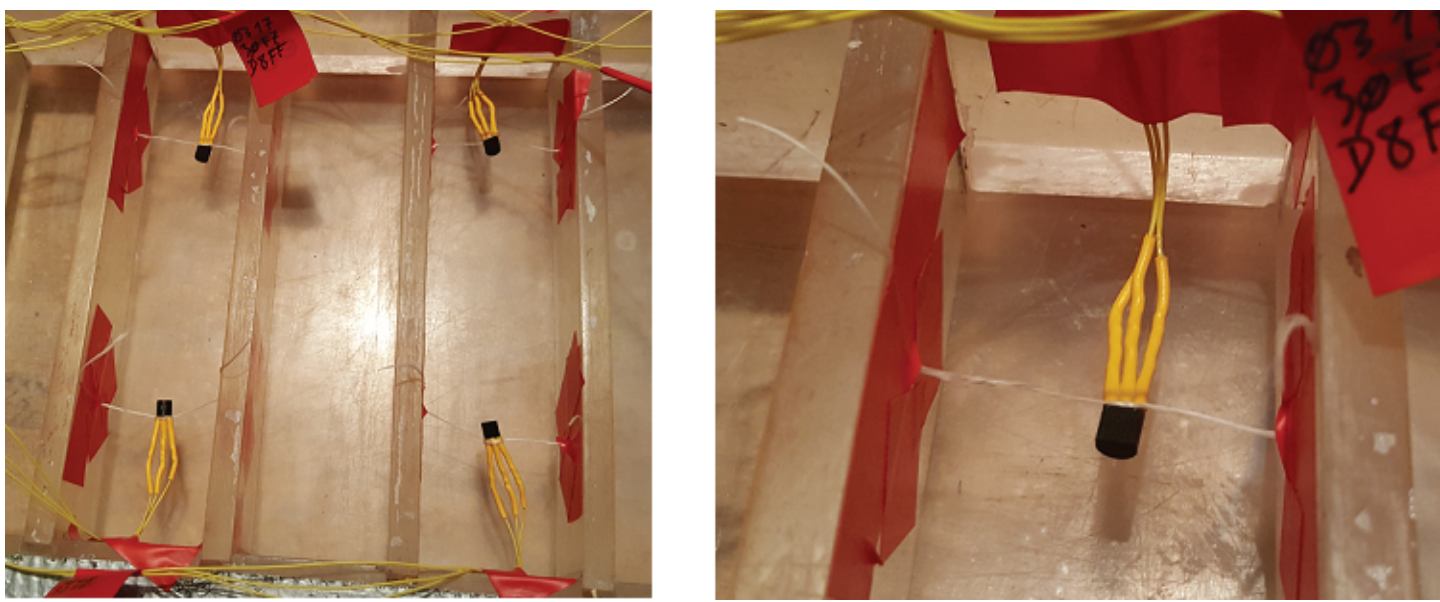

Figure 2: The thermometers stabilized inside the moulds.

\subsection{The tests results and the discussion}

The strength test results are presented in form of the bar graphs. The average value of the flexural or compressive strength from each group of samples is given above each bar. The small black line segments represent the extreme values obtained in each series of samples. The lower line segment state for the minimum value and the upper one - for the maximum.

\subsubsection{The influence of the curing temperature on the geopolymers strength}

The first graph (Figure 3) presents the influence of the curing temperature and curing conditions on the strength of the FBC fly ash based geopolymer. The $\mathrm{X}$ axis describes the temperature conditions in which samples were cured for the first 24 hours (after this time all samples were cured at the room temperature). Samples described in the graph as " $20^{\circ} \mathrm{C} \mathrm{I"} \mathrm{were} \mathrm{demoulded} \mathrm{after} 24$ hours while samples described as " $20^{\circ} \mathrm{C}$ II" were kept in the moulds until the end of the curing time. Samples from the " $20^{\circ} \mathrm{C} \mathrm{I"}$ series were affected by the visible, significant shrinkage and efflorescence. After 7 days they lost about $3 \mathrm{~mm}$ of its length and $1 \mathrm{~mm}$ of the width. The big shrinkage was caused probably by the fact, that samples were demoulded quickly and in consequence all surfaces had contact with the air before the reactions inside the geopolymer matrix were finished. The cracks from the upper and side surfaces are shown in the Figure 4.

The graph shows that the compressive strength increases with the increase of the curing temperature but the difference between the average compressive strength of samples cured at $20^{\circ} \mathrm{C}$ and $40^{\circ} \mathrm{C}$ is almost negligible. In case of the flexural strength, 
it can be seen, that strength of the samples cured in the climatic chamber at elevated temperature for the first $\mathbf{2 4}$ hours is higher than of samples cured all the time at the room temperature.

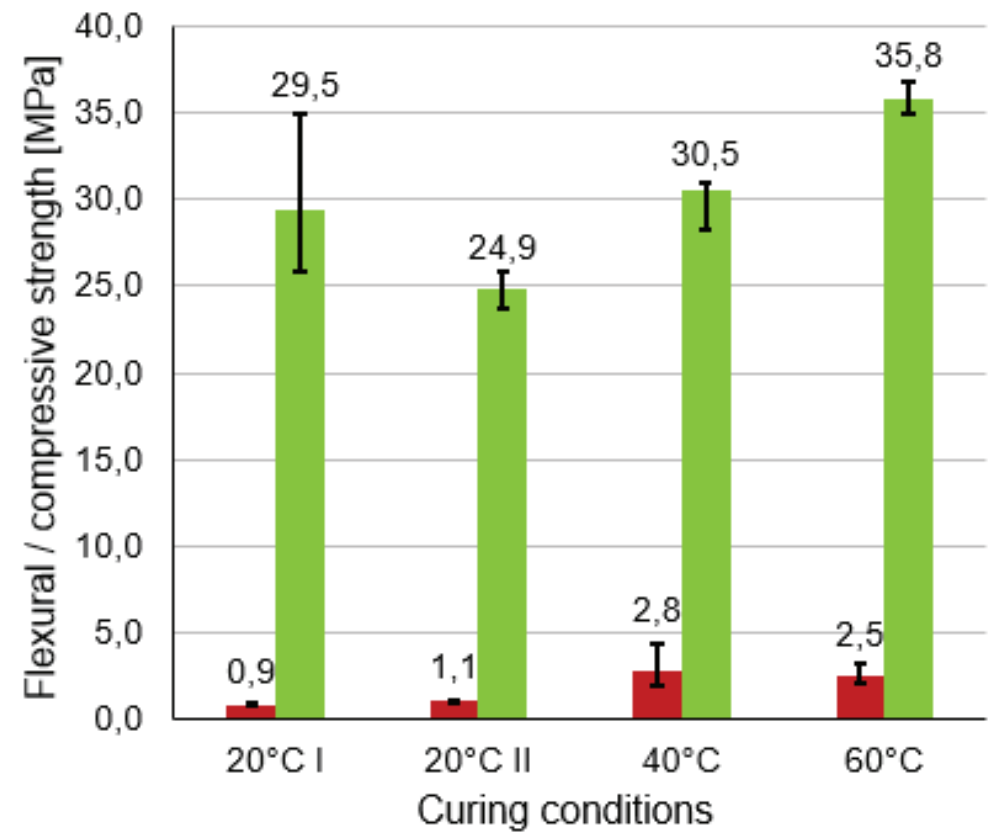

- Flexural strength

n Compressive strength

Figure 3: Flexural and compressive strength of FBC fly ash based geopolymer cured in different temperatures (after 7 days).

What is unexpected, the samples from the batch $20^{\circ} \mathrm{C} \mathrm{II} \mathrm{(demoulded} \mathrm{after} 7$ days), obtained smaller compressive strength and almost the same flexural strength as samples from the batch $20^{\circ} \mathrm{C}$, which were demoulded after 24 hours. Surface of samples cured at the room temperature and demoulded after 24 hours was covered with cracks while surface of samples demoulded after 7 days was plain. It was expected that samples from the second batch $\left(20^{\circ} \mathrm{C} \mathrm{II}\right)$ obtained higher strength.
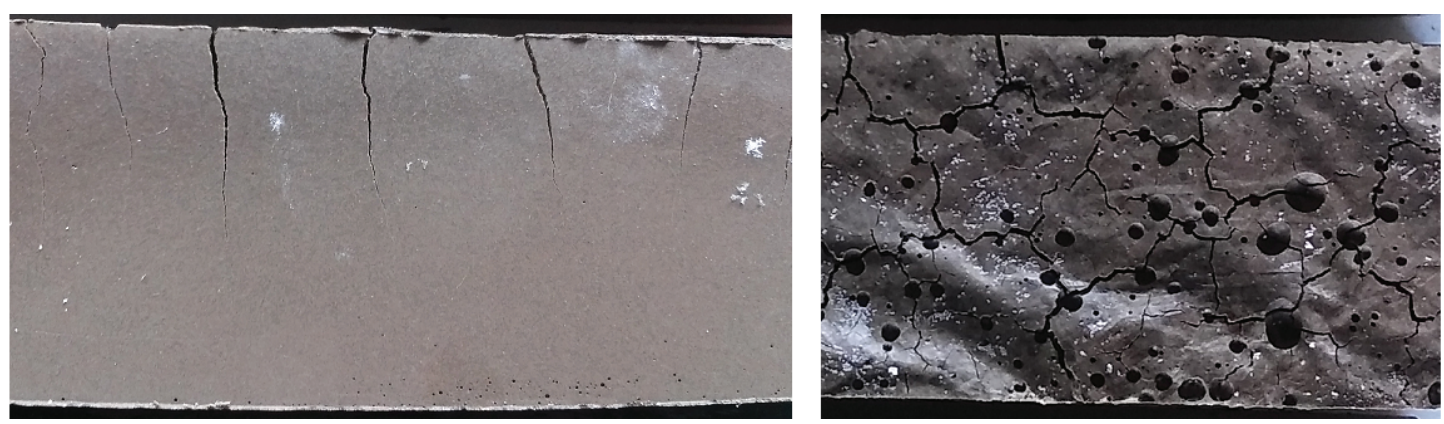

Figure 4: Cracked, side and upper surface of samples cured in $20^{\circ} \mathrm{C}$ and demoulded after 24 hours.

Nevertheless, the test has shown that the fly ash-based geopolymer should not be demoulded after 24 hours while cured at the room temperature because cracks and significant shrinkage are unwanted and dangerous features. Also, the divergence of the 
results within one batch was the most significant in the case of the cracked samples probably because of the different extent of the damage.

Each sample was weighed and measured before the strength tests. The density of geopolymers from each batch was obtained by dividing the mass of the samples by its volume. Table 3 contains densities of the geopolymers cured in different temperatures and in different conditions. It was observed that the density is decreasing with the increase of the curing temperature. The higher density of the samples cured at room temperature is probably caused by the greater amount of not evaporated water inside the structure. No difference between density of the samples cured the room temperature, demoulded after 24 hours and demoulded after 7 days was noticed.

TABLE 3: Density of the samples cured in different conditions.

\begin{tabular}{|c|c|c|c|c|}
\hline & $20^{\circ} \mathrm{C}$ & $20^{\circ} \mathrm{C} \mathrm{I}$ & $40^{\circ} \mathrm{C}$ & $60^{\circ} \mathrm{C}$ \\
\hline Density $\left[\mathrm{kg} / \mathrm{m}^{3}\right]$ & 1750 & 1750 & 1580 & 1530 \\
\hline
\end{tabular}

The dependence between the curing temperature and the strength of different kinds of a geopolymer was a subject of many papers. Bakri et al. report that the compressive strength of a fly ash based geopolymer is increasing significantly with the increase of the curing temperature from $20^{\circ} \mathrm{C}$ to $50^{\circ} \mathrm{C}$ and further, to $60^{\circ} \mathrm{C}$ [15]. The strength of samples cured at $70^{\circ} \mathrm{C}$ and $80^{\circ} \mathrm{C}$ is much lower than of those cured at $50^{\circ} \mathrm{C}$ and $60^{\circ} \mathrm{C}$. Tests were done after 7 days. Conversely, Hardjito et $a$ report that the strength of a fly ash based geopolymer increases with each growth in the curing temperature, however, the difference between strength of samples cured at $30^{\circ} \mathrm{C}$ and $60^{\circ} \mathrm{C}$ is much bigger than between $60^{\circ} \mathrm{C}$ and $90^{\circ} \mathrm{C}$ [16]. Sun et al. registered that the difference between compressive strength (measured after 7 days) of the geopolymer cured at $60^{\circ} \mathrm{C}$ for 24 hours and at $40^{\circ} \mathrm{C}$ is much bigger (over 250\%) than between samples cured at $30^{\circ} \mathrm{C}$ and $40^{\circ} \mathrm{C}$ (about 180\%) [17]. However, the difference is decreasing in time and after 96 days it is almost negligible. The flexural strength behaves in almost the same way. Zhang et al. prove that after 7 days, compressive strength of a red mud-fly ash based geopolymer is bigger for higher curing temperatures (range of temperatures used during the test: $23^{\circ} \mathrm{C}, 50^{\circ} \mathrm{C}, 80^{\circ} \mathrm{C}$ ) [18]. However, the long-term compressive strength is not further monotonically dependant on the curing temperature. After 49 days, strength of the samples cured at $80^{\circ} \mathrm{C}$ is lower than of samples cured at $23^{\circ} \mathrm{C}$ and $50^{\circ} \mathrm{C}$. On the contrary, after 90 days the strength of all samples is almost the same but after 120 days there is an evident dependence: the higher curing temperature, the higher strength. Zhang et al. also noticed also that the density of a geopolymer is decreasing with the increase of the curing temperature what is consistent with results presented in the 
presented paper. Some investigations disagree with the statement that the strength is increasing with the increase of the curing temperature till some level. Rovnanik noted the very similar strength (both compressive and flexural) of the metakaolin based samples cured at $20^{\circ} \mathrm{C}$ and $40^{\circ} \mathrm{C}$ after 7 days and of samples cured at $10^{\circ} \mathrm{C}, 20^{\circ} \mathrm{C}$ and $40^{\circ} \mathrm{C}$ after 28 days [19]. He noted also that the strength of the samples cured at higher temperatures $\left(60^{\circ} \mathrm{C}\right.$ and $\left.80^{\circ} \mathrm{C}\right)$ is significantly smaller. He reports the decrease of the density with the increase of the curing temperature. By contrast, Yuan et al. indicate that when metakaolin based geopolymer is cured longer at the elevated temperatures (5 days), its strength increases considerably with the increase of curing temperatures [20]. It is lower only for samples cured at $90^{\circ} \mathrm{C}$. Almost the same dependence between the curing temperature and strength was determined by [21]. The investigation was done on the fly ash based geopolymer. Ekaputri et al registered the increase of the strength of a metakaolin based geopolymer with the growth of the curing temperature but the differences were small, especially considering the long-term effects [22]

It is proved that the influence of the curing temperature on the geopolymer mechanical characteristics is dependant on the time of curing and the age of the tested geopolymer. Investigation done by Swanepoel et al. shows that the seventh day compressive strength of the geopolymer cured for 24 hours at different temperatures increases in the following manner: $60^{\circ} \mathrm{C}=70^{\circ} \mathrm{C}<40^{\circ} \mathrm{C}<50^{\circ} \mathrm{C}$ while for samples cured for 72 days the dependences are different: $40^{\circ} \mathrm{C}<50^{\circ} \mathrm{C}<60^{\circ} \mathrm{C}<70^{\circ} \mathrm{C}$ [23]. According to this study, the density of a geopolymer measured after 7 days is decreasing with the growth of the curing temperature. After 28 days, the density of all samples was almost the same.

\subsubsection{The change of the temperature inside the geopolymer during the curing process}

Figure 5 presents a diagram of a temperature changes inside the FBC fly ash based geopolymer during the first 18 hours of curing. The temperature was measured on the two-opposite end of two samples. Four thermometers were used in that research. The temperature inside geopolymer was measured since placing the mixture inside the mould. The diagram starts with jump of the temperature what means that temperature of the geopolymer mixture had to grow up already during the mixing of the fly ash with the activators. The maximum temperature was registered after 1 to 2 min in dependence on the thermometer. The maximum registered temperature ranged between $27.00^{\circ} \mathrm{C}$ and $27.63^{\circ} \mathrm{C}$. The maximum temperature continued for about 1 min and then started to decline gradually until it reached the room temperature after about 16 hours of curing. 
The divergences between measurements done by thermometers are small (generally smaller than $\left.0.5^{\circ} \mathrm{C}\right)$.

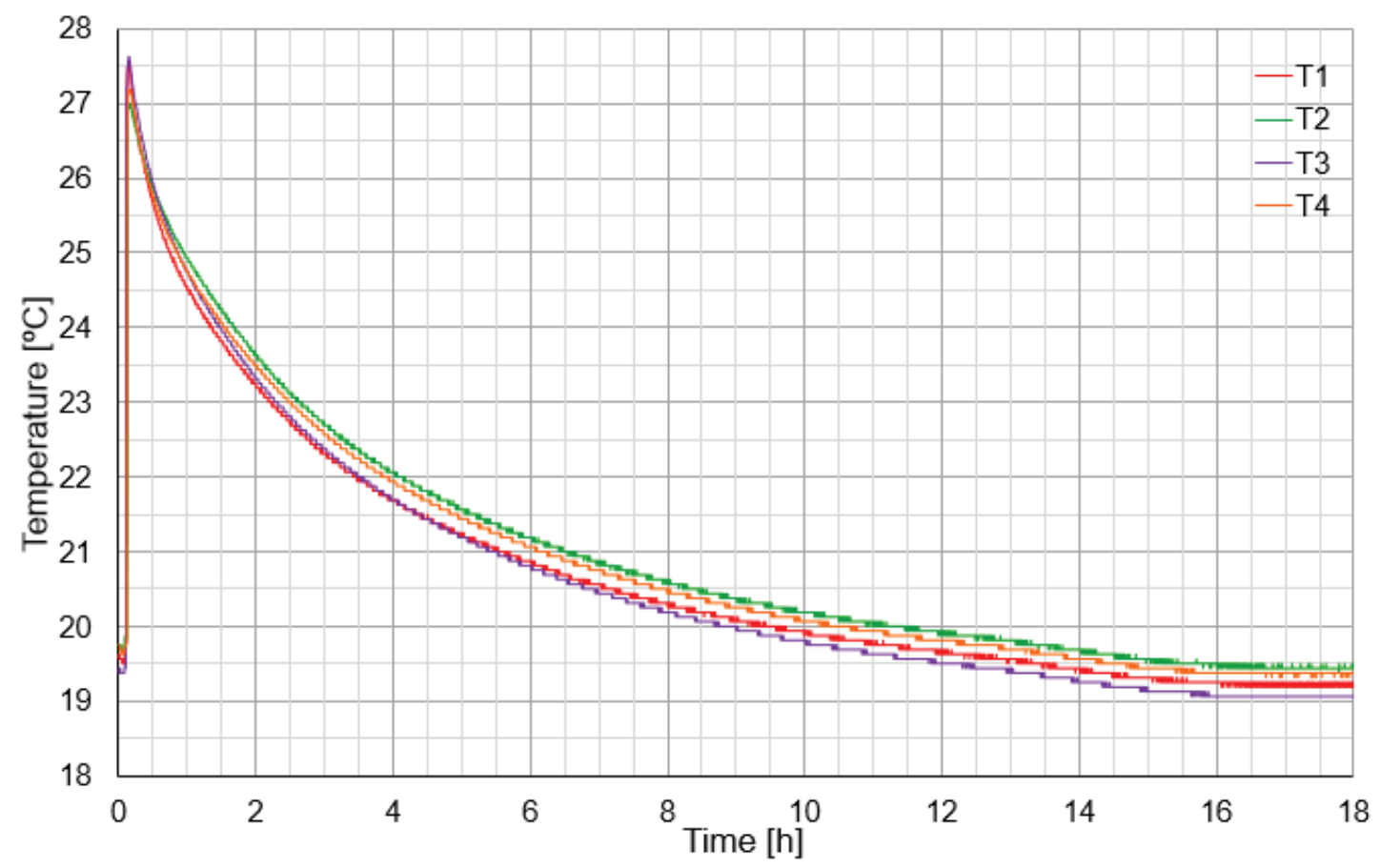

Figure 5: The temperature changes in geopolymer samples during the first 18 hours of curing.

\subsubsection{The change of geopolymer strength in time}

The influence of the time on the strength of the FBC fly ash based geopolymer was determined on the samples cured for the first 24 hours at temperature $40^{\circ} \mathrm{C}$. The strength results of the samples cured in that conditions were relatively high and stable. In addition, the lower curing temperature, the better for an environment.

Figure 6 presents flexural and compressive strength of the FBC fly ash based geopolymer tested after 1, 5, 7, 14 and 100 days. According to the graph, the compressive strength is gained quickly. Immediately after demoulding (after 24 hours of curing) the average compressive strength was equal to $25.2 \mathrm{MPa}$. In the following 4 days, the compressive strength increased to about $30 \mathrm{MPa}$ and stabilized. The long-term compressive strength test showed the increase in strength by over $26 \%$ in comparison to the strength measured after 14 days. It means that probably the FBC fly ash based geopolymer is not losing its strength in time. However, the strength should be measured after even longer time to prove this trend.

The flexural strength behaves in less stable way. The differences are bigger, and it is hard to determine the clear dependence between the age and the flexural strength 


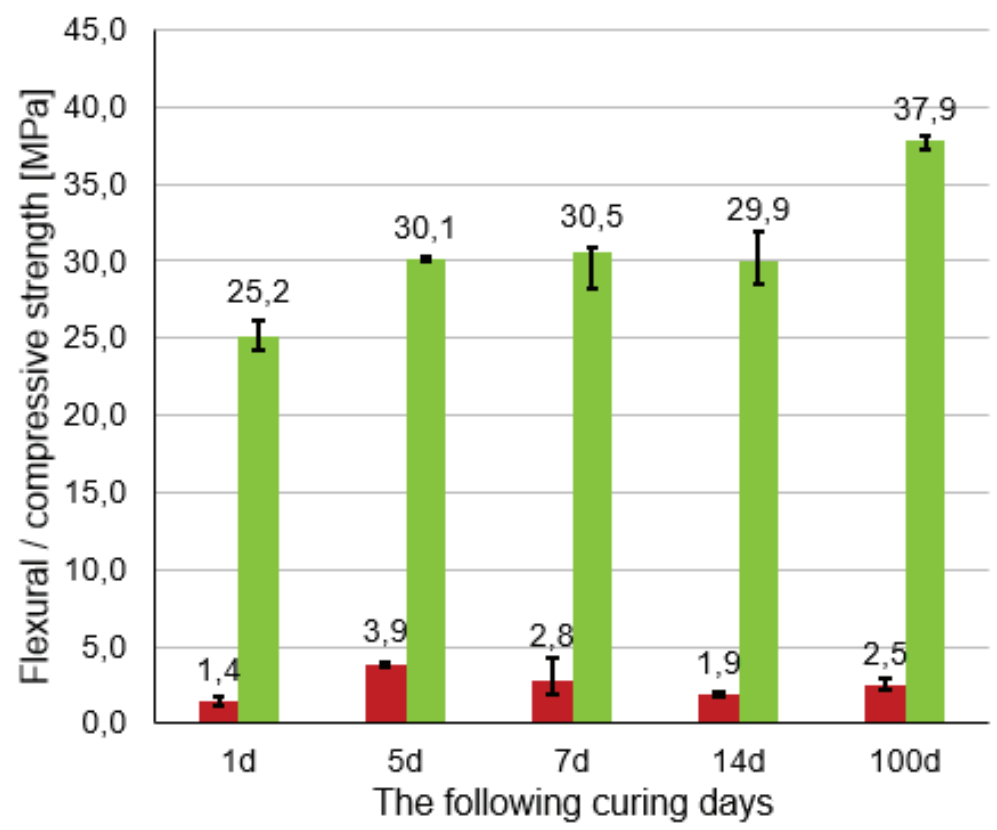

- Flexural strength

- Compressive strength

Figure 6: Flexural and compressive strength of FBC fly ash based geopolymer after 1, 5, 7, 14 and 100 days.

of the FBC fly ash based geopolymer. The smallest flexural strength was registered during the first day of curing. Then, the flexural strength increased and dropped again significantly after 7 and 14 days. The big differences show that the flexural strength should be examined carefully once again in the future on the greater amount of samples.

Table 4 contains densities of geopolymers measured after 1, 5, 7, 14 and 100 days. It can be seen that the density is generally decreasing in time. The only exception is the density after 7 days which is smaller than the density after 14 days. The difference can be possibly caused by the less compaction. It should be noticed that the FBC fly ash based geopolymer is generally characterized by the small density what can be treated as a big advantage of this material.

TABLE 4: Changes of the density in time.

\begin{tabular}{|l|c|c|c|c|c|}
\hline & $1 d$ & $5 d$ & $7 d$ & $14 d$ & $100 d$ \\
\hline Density $\left[\mathrm{kg} / \mathrm{m}^{3}\right]$ & 1730 & 1660 & 1580 & 1620 & 1490 \\
\hline
\end{tabular}

Swanepoel et al. [23] reports a big increase between $7^{\text {th }}$ day and $28^{\text {th }}$ day compressive strength of the fly ash-based samples cured at elevated temperatures for the 24 hours. $\mathrm{He}$ also mentions the decrease in the density in time. By contrast, results obtained by Chindaprasirt et al. [1] show almost negligible differences in compressive strength of an FBC fly ash based geopolymer tested after 7, 30, 90 and 180 days. The strength of the geopolymer tested after 30 days is slightly greater than of this tested after 7 days. After 90 days the strength falls down by about $1 \mathrm{MPa}$ and then increases again 
after 180 days. The geopolymer was cured at a room temperature. Hardjito et al. [16] also present results proving almost negligible influence of age (tests done in the range 3-90days) of a fly ash based geopolymer on its strength. Almost final compressive strength was registered after 3 days. The later changes do not exceed a few percent. The maximum compressive strength was registered after 14 days. The samples were cured at $60^{\circ} \mathrm{C}$ for 24 hours. Criado et al. indicate that the exact behaviour of a fly ash based geopolymer in time depends on the kind of activators and the curing method [24]. Nevertheless, in all showed cases, the compressive strength is increasing in time. Tests were done after 5, 12 and 20 hours and after 7 days. Sun et al. presents results which show prominent changes of both flexural and compressive strength of a fly ash based geopolymer in time, especially in case of samples cured at $30^{\circ} \mathrm{C}$ and $40^{\circ} \mathrm{C}$ [17]. According to the research, the compressive strength of these samples stabilizes only after 96 days of curing. The flexural strength is still growing after 96 days, but more steadily than before. The samples cured at $60^{\circ} \mathrm{C}$ reach high compressive strength just after 3 days, then the increase is not very big, and it is steady.

\section{Conclusions}

The paper presents a research on the fluidized bed combustion (FBC) fly ash based geopolymer. The three main issues were considered during the research: the influence of the curing temperature on the geopolymer strength; the changes of the geopolymer strength in time and the changes of the temperature inside the geopolymer during the curing process. The following main conclusions were drawn:

The compressive strength increases with the increase of the curing temperature. The behaviour of the flexural strength is not monotonic and not strictly dependent on the curing temperature.

Samples cured all the time at the room temperature and demoulded after 24 hours were affected by significant shrinkage and cracks.

The temperature inside the FBC fly ash based geopolymer increases rapidly during mixing of the mixture. Then, the temperature is falling down steadily until it reaches the room temperature. The highest registered average temperature was equal to $27.34^{\circ} \mathrm{C}$.

The compressive strength of the FBC fly ash based geopolymer cured at $40^{\circ}$ for the first 24 hours, gained the high compressive strength after 1 day and almost the final compressive strength after 5 days. In long time perspective, the compressive strength has tendency to increase. The general trend of the flexural strength is hard to be predicted. 


\section{References}

[1] Chindaprasirt, P., Jenjirapanya, S., Rattanasak, U. (2014). Characterizations of FBC/PCC fly ash geopolymeric composites. Construction and Building Materials, vol. 66 , pp.72-78.

[2] Glinicki, M.A., Zieliński, M. (2008). The influence of CFBC fly ash addition on phase composition of air-entrained concrete. Bulletin of Polish Academy of Sciences, Technical Sciences, vol. 56, no. 1, pp. 45-52

[3] Brzozowski, P. (2011). Możliwości wykorzystania popiołów lotnych ze spalania w kotłach fluidalnych do betonów układanych pod wodą. Budownictwo i Inżynieria Środowiska, vol. 2, pp. 5-11.

[4] Giergiczny, Z. (2019). Fly ash and slag. Cement and Concrete Research, vol. 124, 10582.

[5] Siler, P., Bayer, P., Sehnal, T., Kolarova, I., Opravil, T., Soukal, F. (2015). Effects of hightemperature fly ash and fluidized bed combustion ash on the hydration of Portland cement. Construction and Building Materials, vol. 78, pp. 181-188.

[6] Glinicki, M.A., Jóźwiak-Niedźwiedzka, D., Dąbrowski, M. (2019). The Influence of Fluidized Bed Combustion Fly Ash on the Phase Composition and Microstructure of Cement Paste. Materials, vol. 12, 2838.

[7] Chi, M. (2016). Synthesis and characterization of mortars with circulating fluidized bed combustion fly ash and ground granulated blast-furnace slag. Construction and Building Materials, vol. 123, pp. 565-573.

[8] Haniskova, D., Bartonickova, E., Koplik, J., Opravil, T. (2016). The ash from fluidized bed combustion as a donor of sulfates to the Portland clinker. Procedia Engineering, vol. 151, pp. 394-401.

[9] Song, Y., Guo, C., Qian, J., Ding, T. (2015). Effect of the Ca-to-Si ratio on the properties of autoclaved aerated concrete containing coal fly ash from circulating fluidized bed combustion boiler. Construction and Building Materials, vol. 83, pp. 136-142.

[10] Zhang, Z., Qian, J., You, C., Hu, C. (2012). Use of circulating fluidized bed combustion fly ash and slag in autoclaved brick. Construction and Building Materials, vol. 35, pp. 109-116.

[11] Wu, W., Matalkah, F., Darsanasiri, A.G.N.D., Soroushian, P. (2019). Fluidized bed combustion coal fly ash: comparative evaluation for potential use in alkali-activated binders. International Journal of Coal Preparation and Utilization.

[12] Oyun-Erdene, G., Temuujin, J. (2019). Effect of Mechanical Activation of Fluidized Bed Fly Ash on Geopolymer Properties, Solid State Phenomena, vol. 288, pp. 51-58. 
[13] Duan, P., Yan, C., Zhou, W., Luo, W., Shen, C. (2015). An investigation of the microstructure and durability of a fluidized bed fly ash-metakaolin geopolymer after heat and acid exposure. Materials and Design, vol. 74, pp. 125-137.

[14] EN 196-1:2016, Method of testing cement - Part 1: Determination of strength, Brussels 2016.

[15] Mustafa Al Bakri, A.M., Kamarudin, H., BinHussain, M., Khairul Nizar, I., Zarina, Y., Rafiza, A.R. (2011). The Effect of Curing Temperature on Physical and Chemical Properties of Geopolymers. Physics Procedia, vol. 22, pp. 286-291.

[16] Hardjito, D., Rangan, B.V. (2005). Development and properties of low-calcium fly ash-based geopolymer concrete. Research Report GC1. Perth, Australia. Faculty of Engineering, Curtin University of technology.

[17] Sun, Z., Vollpracht, A. (2019). One year geopolymerisation of sodium silicate activated fly ash and metakaolin geopolymers. Cement and Concrete Composites, vol. 95, pp. 98-110.

[18] Zhang, M., Zhao, M., Zhang, G., Sietins, J.M., Granados-Focil, S., Pepi, M.S., Xu, Y., Tao, M. (2018). Reaction kinetics of red mud-fly ash based geopolymers: Effects of curing temperature on chemical bonding, porosity, and mechanical strength. Cement and Concrete Composites, vol. 93, pp. 175-185.

[19] Rovnanik, P. (2010). Effect of curing temperature on the development of hard structure of metakaolin-based geopolymer. Construction and Building Materials, vol. 24, pp. $1176-1183$.

[20] Yuan, J., He, P., Jia, D., Yang, C., Zhang, Y., Yan, S., Yang, Z., Duan, X., Wang, S., Zhou, Y. (2016). Effect of curing temperature and $\mathrm{SiO} 2 / \mathrm{K} 2 \mathrm{O}$ molar ratio on the performance of metakaolin-based geopolymers. Ceramics International, vol. 42, pp. 16184-16190.

[21] Chindaprasirt, P., Chareerat, T., Sirivivatnanon, V. (2007). Workability and strength of coarse high calcium fly ash geopolymer. Cement and Concrete Composites, vol. 29, pp. 224-229.

[22] Ekaputri, J.J., Junaedi, S, Wijaya (2017). Effect of curing temperature and fiber on metakaolin-based geopolymer. Procedia Engineering, vol. 171, pp. 572-583.

[23] Swanepoel, J.C., Strydom, C.A. (2002). Utilisation of fly ash in a geopolymeric material. Applied Geochemistry, vol. 17, pp. 1143-1148.

[24] Criado, M., Palomo, A., Fernandez-Jimenez, A. (2005). Alkali activation of fly ashes. Part 1: Effect of curing conditions on the carbonation of the reaction products, Fuel, vol. 84, 2048-2054. 